\title{
Influence of Land Use Land Cover Change on Groundwater Recharge in the Continental Terminal Area of Abidjan, Ivory Coast
}

\author{
Kouakou Koffi Abdelazizi" ${ }^{*}$, Yalo Nicaise², Luc Séguis ${ }^{3}$, Ismaïla Ouattara4, Ouédraogo Moussa4, \\ Kouassi Kouamé Auguste ${ }^{4}$, Bamory Kamagaté4, Koné Diakaria5
}

\author{
${ }^{1}$ Graduate Research Program on Climate Change and Water Resources, West African Science Service Center on Climate Change \\ and Adapted Land Use (WASCAL), Department of Applied Hydrology, Cotonou, Benin \\ ${ }^{2}$ Laboratory of Applied Hydrology, National Water Institute, University of Abomey-Calavi, Cotonou, Benin \\ ${ }^{3}$ Ird, Institute of Research and Development, Université de Montpellier, Montpellier, France \\ ${ }^{4}$ Laboratoire GeoSciences et Environnement (LGE), UFR Sciences et Gestion de Environnement (SGE), University of Nangui \\ Abrogoua (UNA), Abidjan, Côte d'Ivoire \\ ${ }^{5}$ Direction des ressources en eau (DRE), Office National de l'Eau Potable (ONEP), Abidjan, Côte d'Ivoire \\ Email: *kalex8139@gmail.com
}

How to cite this paper: Abdelaziz, K.K., Nicaise, Y., Séguis, L., Ouattara, I., Moussa, O., Auguste, K.K., Kamagaté, B. and Diakaria, K. (2020) Influence of Land Use Land Cover Change on Groundwater Recharge in the Continental Terminal Area of Abidjan, Ivory Coast. Journal of Water Resource and Protection, 12, 431-453.

https://doi.org/10.4236/jwarp.2020.125026

Received: April 10, 2020

Accepted: May 19, 2020

Published: May 22, 2020

Copyright $\odot 2020$ by author(s) and Scientific Research Publishing Inc. This work is licensed under the Creative Commons Attribution International License (CC BY 4.0).

http://creativecommons.org/licenses/by/4.0/ (c) (i) Open Access

\begin{abstract}
The process by which rainfall reaches the aquifer in a sedimentary area is infiltration. This process could be affected quantitatively or qualitatively by the changes in the land use land cover (LULC) as a result of anthropogenic activities which could affect groundwater reserves. This study focuses on the influence of LULC change on groundwater recharge in the context of urbanization and population growth. Four weather stations data and satellite image data were used in order to evaluate water infiltration which is the amount of water that reaches the piezometric surface from 1990 to 2016. The spatial-temporal LULC change in relation to urbanization sprawl was assessed based on a series of Landsat images for 1990, 2000 and 2016. The maximum likelihood pixel-based on classification method was used to analyze the spatial-temporal LULC dynamics. The Thiessen polygon method was used for the mean area precipitation computation. The recharge was determined using water balance method after determining the runoff based on the Soil Conservation Service curve number method. The results show an increase in built-up and agricultural land, while the forest and shrub areas declined with water body remaining unchanged over the period 1990-2016. The decline in forest could be imputed to the demographic and socio-economic growth as expressed by the expansion of agriculture and urbanization. Groundwater recharge and runoff results are respectively $34 \%, 20 \%$ in $1999 ; 21 \%, 46 \%$ in
\end{abstract}


2000 and 26\%, 14\% in 2016 of rainfall and show their strong dependence on precipitation and LULC change.

\section{Keywords}

Groundwater Recharge, Runoff, LULC, SCS Curve Number, Continental Terminal, Abidjan

\section{Introduction}

Nowadays, over $50 \%$ of the Earth's population now lives in cities and it is estimated that by 2025 this leads to an increase in population over $67 \%$ [1]. The anthropogenic activities on the environment increase impervious cover and storm drains that channel precipitation off roads [2]. Impervious cover is a major index of urbanized areas and is considered the most pervasive, relevant characteristic leading to hydrologic impacts [3]. Furthermore, the rapid growth of urban areas has two basic effects on groundwater resources, such as effects on natural recharge of aquifers due to sealing of ground with concrete, and pollution of groundwater due to leakage from drainage and, industrial wastes and effluents [4]. Nevertheless the contribution of groundwater, the part of groundwater in water consumption is extremely important for water supply for most of the urban area [5]; therefore it will be important to analyze urbanization influence on groundwater. In this study, we will see the case study of Abidjan groundwater. Continental Terminal aquifer in the South East of Ivory Coast, commonly known as Abidjan aquifer, is the only source of drinking water supply in the Abidjan district since the independence of Ivory Coast. This unconfined groundwater plays an important role providing water for the population of Abidjan city. They need to supply water for private, public, agriculture, industrial and commercial uses. The population has increased considerably in recent decades due to an exodus of population from north to south. This growth has been accompanied by strong urbanization and uncontrolled industrial growth [6]. The variability of precipitation and the urbanization process affect more and more the quality and the quantity of this aquifer [7] [8]. For instance, the decrease of piezometric level results from the increase of soil sealing. In fact, water infiltration process depends on the grounds slope, the unsaturated zone and the LULC [9]. Therefore the increase in bare soils and urbanized areas contributed to a decrease in infiltration and take advantage of runoff [10].

Relevant studies were carried out by several researchers [11]-[17] in the past. These researches highlight several methods for determining the recharge, such as water table fluctuation method and the water balance method. Water Table Fluctuation is the most used, especially in the context of shallow unconfined aquifers. It is simple, easy to use. The main constraint of the method is based on the difficulty of evaluating the specific storage coefficient (Sy), which directly 
controls the estimated value of the recharge. This method also considers that any rise in the water level of the water table is due to recharge. However, water pumping or evapotranspiration could question this hypothesis. For the water balance method, it requires some parameters such as precipitation, runoff and actual evaporation but runoff determination method remains the most important to find a good result of water recharge. Rainfall and runoff are significant sources of water for recharge, therefore, evaluation of water availability by an understanding of rainfall and runoff is essential [18]. The Soil Conservation Service Curve Number method (SCS-CN Method) used in this study to determine runoff comes to overcome the limitations of previous methods. The SCS-CN (1985) method has been established in 1954 by the USDA SCS [19], defined in the Soil Conservation Service (SCS) by National Engineering Handbook (NEH-4) Section of Hydrology [20]. The Soil conversations Service-Curve Number approach is based on the water balance calculation and two fundamental hypotheses had been proposed [21]. This method was used by [22] [23] to estimate runoff potential from rainfall and by [24] in order to assess floodwater. The objective of this study is to estimate surface runoff and groundwater recharge of Abidjan aquifer for the year 1990, 2000 and 2016 using the water balance method taking into account the hydrologic soil group of the area, the different LULC, treatment and hydrologic conditions.

\section{Study Area}

The Continental Terminal (Figure 1), part of the sedimentary zone is located in the south-eastern part of Ivory Coast between Latitudes of $5^{\circ} 10$ and $5^{\circ} 38$ North and Longitudes of $3^{\circ} 45$ and $4^{\circ} 21$ West. It has an area of about $1160 \mathrm{~km}^{2}$ and is located in Abidjan district with an estimated population of 4,707,404 [25] The region is influenced by the transitional equatorial climate and has four seasons in the annual cycle [26] [27] with a long rainy season from March to June, followed by a short dry season between July and August, a small rainy season in September to the end of November and a long dry season from November to February. The average temperature is $27^{\circ} \mathrm{C}$ (monthly temperature range $24^{\circ} \mathrm{C}$ $30^{\circ} \mathrm{C}$ ) and the average annual rainfall recorded in the Abidjan district ranges from $1822 \mathrm{~mm}$ to $1611 \mathrm{~mm}$ over $1960-2016$ period. The area is characterized by fairly low relief with elevation ranging between $-16 \mathrm{~m}$ and $146 \mathrm{~m}$. The LULC at the area is mainly dominated by secondary forests and agricultural area in the North, then savannah of palmyra in the South. There are also several plant landscapes such as dense moisture forest; pre-lagoon savannas; mangroves and swamp forests. According to [28], the soils of the study area (Figure 2) belong to the class of highly desaturated lateritic soils, depleted-modal, on tertiary sands (Continental Terminal). However, the iron formations (levels gravel, fragments of armor and ironstone), classified in depleted soils are more or less reworked frequently in the west of Abidjan in northern and southern border. Also, the sedimentary soil of Abidjan developed on Neogene collection consists of more or 


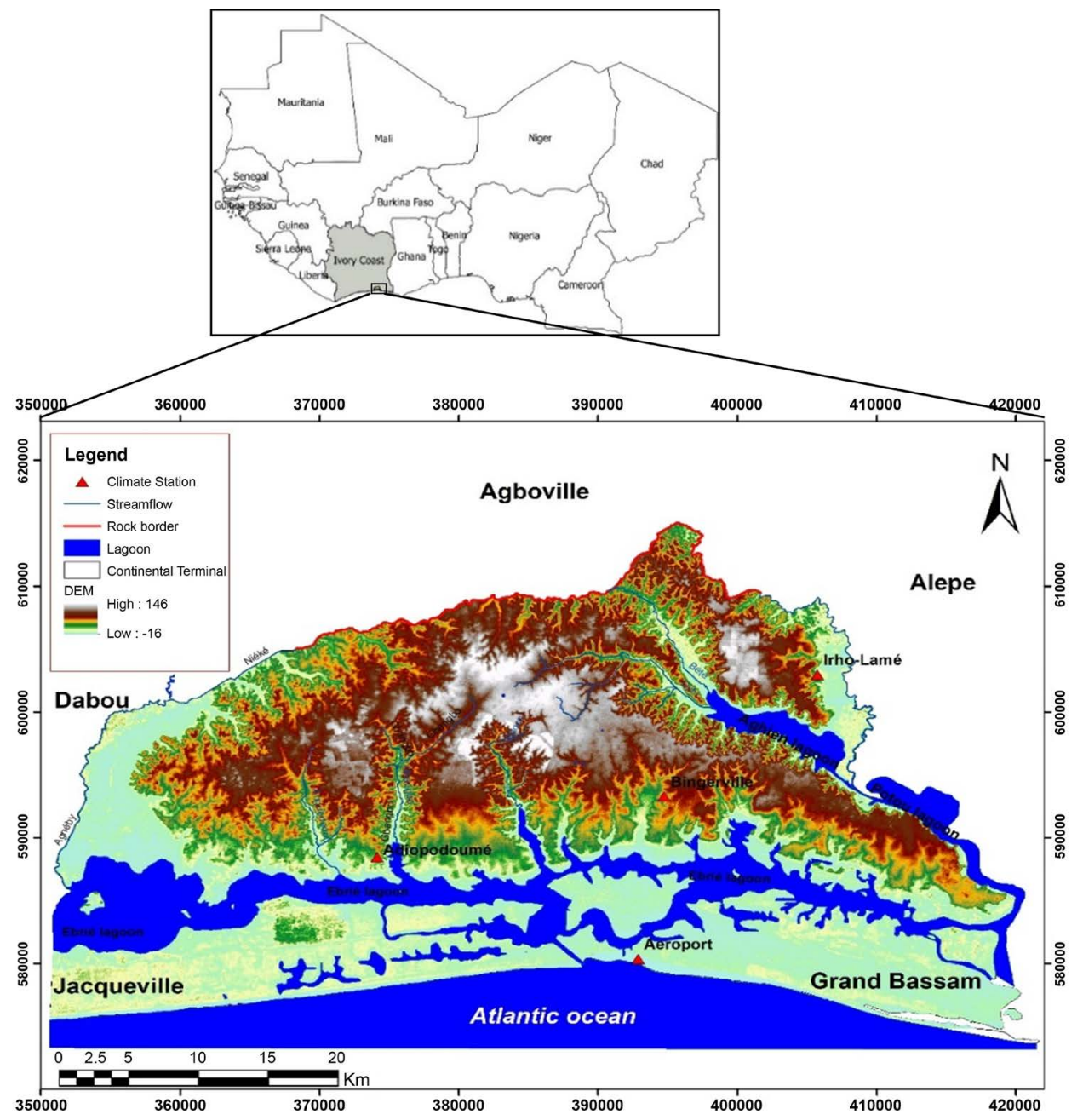

Figure 1. Geographical location of the continental terminal.

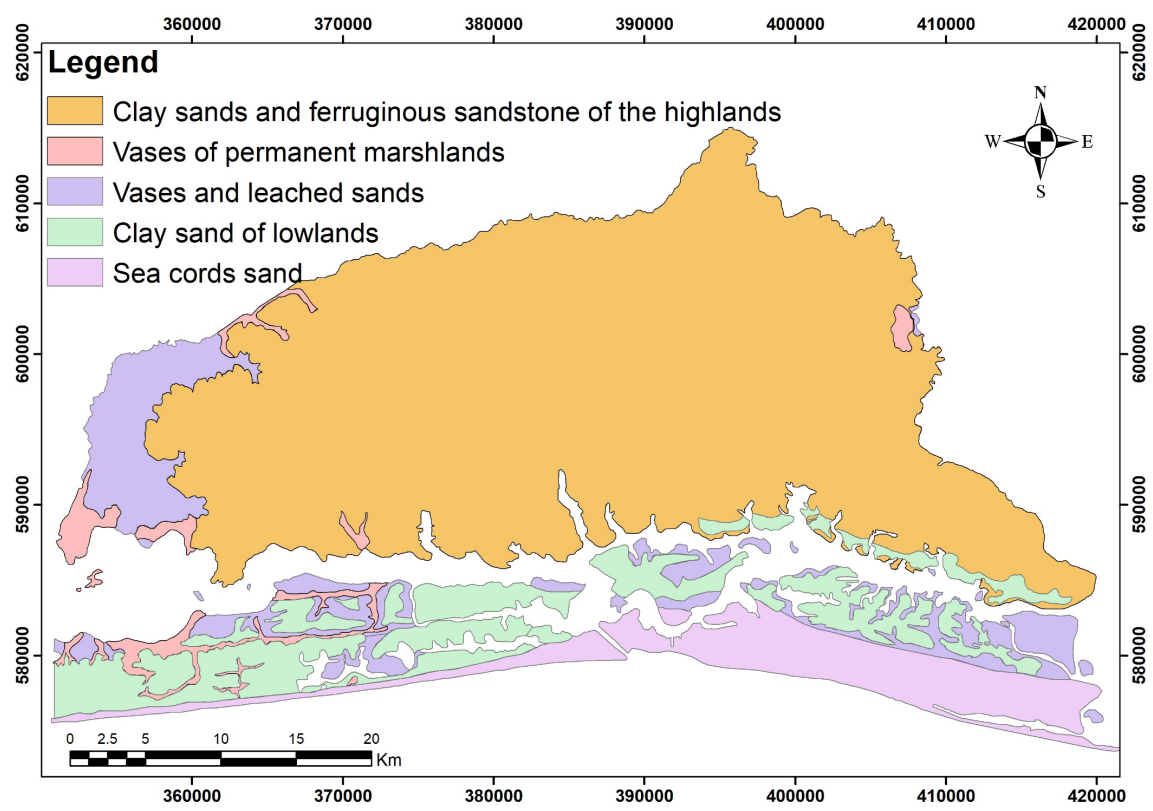

Figure 2. Soil class map used for deriving the hydrological soil group. 
less clayey sands classified in the group of waterlogged soils. Hydromorphic soils, in turn are at the estuary and near the main river.

\section{Data}

\subsection{Climate Data}

There are four meteorological stations situated in the study area (Figure 3), with daily rainfall from 1983 to 2017 and air temperature from 1960 to 2017. Table 1 shows the characteristics of the climate stations used in the study. The climate

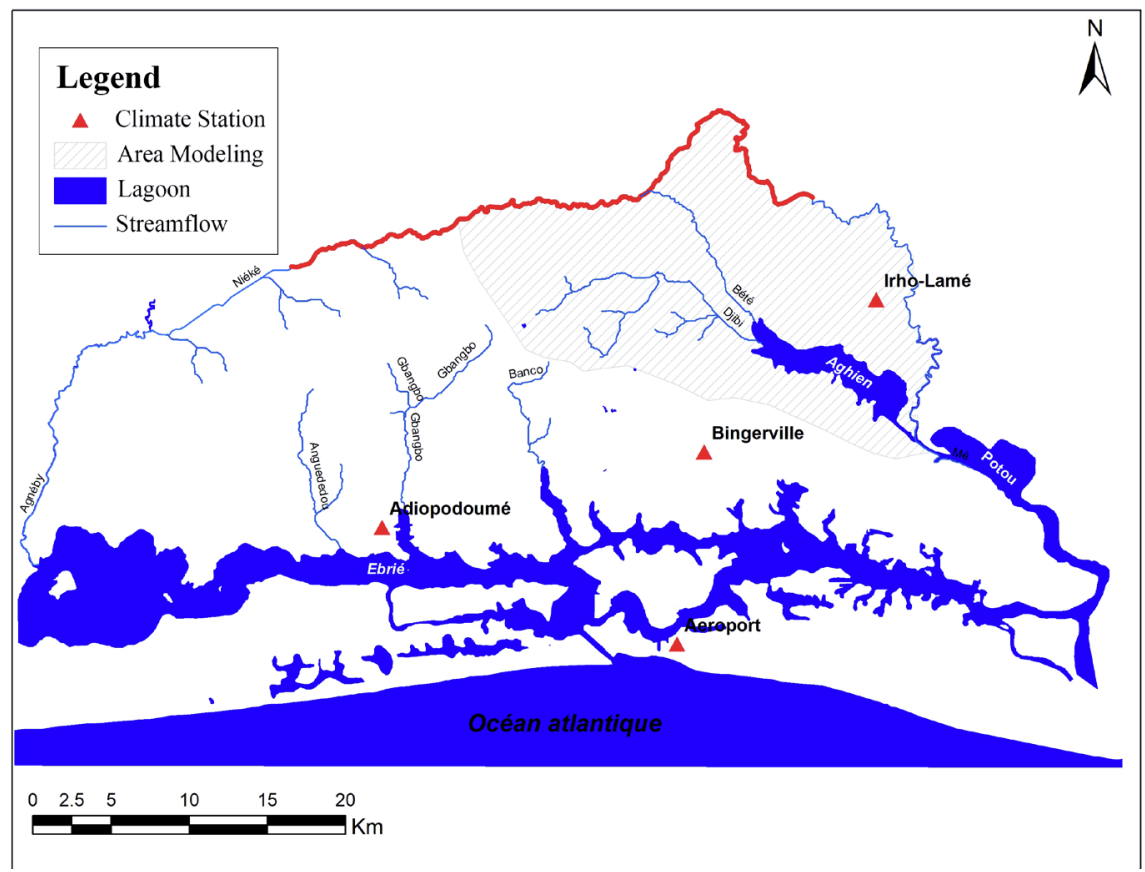

Figure 3. Climate station of the study area.

Table 1. Characteristics of the selected stations and other dataset used in this study.

\begin{tabular}{|c|c|c|c|c|}
\hline Type of data & Scale/resolution & Station & Period & Source of data \\
\hline \multirow{4}{*}{$\begin{array}{c}\text { Rainfall } \\
(\mathrm{mm})\end{array}$} & \multirow{4}{*}{ Daily } & Aeroport & $1960-2017$ & \multirow{4}{*}{$\begin{array}{c}\text { SODEXAM } \\
\text { CNRA }\end{array}$} \\
\hline & & Bingerville & $1960-2017$ & \\
\hline & & Irho-Lamé & $1983-2017$ & \\
\hline & & Adiopodoumé & $1971-2017$ & \\
\hline \multirow{4}{*}{$\begin{array}{c}\text { Temperature } \\
\left({ }^{\circ} \mathrm{C}\right)\end{array}$} & \multirow{4}{*}{ Monthly } & Aeroport & $1960-2017$ & \multirow{4}{*}{$\begin{array}{l}\text { SODEXAM } \\
\text { CNRA }\end{array}$} \\
\hline & & Bingerville & $1960-2017$ & \\
\hline & & Irho-Lamé & $1983-2017$ & \\
\hline & & Adiopodoumé & $1971-2017$ & \\
\hline Landsat & $30 \mathrm{~m}(1990,2000,2016)$ & - & - & www.earthexplorer.usgs.gov/ \\
\hline Soil & $1: 200,000$ & - & - & $\begin{array}{c}\text { Geographic Institute of Côte } \\
\text { d'Ivoire (IGT), } 1992\end{array}$ \\
\hline DEM & $30 \mathrm{~m}$ & - & - & https://gdex.cr.usgs.gov/gdex/ \\
\hline
\end{tabular}


data from the four climate stations were provided by SODEXAM (Société d'Exploitation et de Développement Aéroportuaire et Météorologique) and NCAR (National Center of Agronomical Research).

\subsection{Land Use/Land Cover Data}

Available from the United States Geological Surveys (USGS) archives, data from the Landsat Thematic Mapper (TM), the Enhanced Thematic Mapper (ETM) and the Operational Land Imager (OLI) were assessed for the years 1990, 2000 and 2016 respectively to study the LULC changes in order to determine the urbanization rate at the study area. To ensure the best quality, the driest and cloudless months (December to February) datasets were downloaded. Two (2) scenes are necessary to cover the Continental Terminal zone corresponding to the following paths/rows: 195/56 and 196/56. All images downloaded were already geometrically corrected and georeferenced to the Universal Transverse Mercator (UTM) projection WGS84 zone 30 north.

After the completion of the ordered data, it was processed and classified using the maximum likelihood pixel-based supervised classification method.

\section{Methodology}

\subsection{Mean Areal Precipitation Estimation at a Spatial Scale}

Thiessen polygon method is used for computing the mean area precipitation for a catchment from rain gauge observations. One of the assumptions of this method is that linear rainfall distribution exists; hence, many researchers recommend that the use of the method should be restricted to relatively flat areas with linear rainfall distribution. Arguments remain, however, concerning the optimal gauge density and spacing conditions for its application. Several authors recommend the method's use for areas characterized by a relatively dense and uniformly spaced rain-gauge network. [29] for example, considers that the method is satisfactory with even rainfall distribution, a good 3.2. Unigauge network, and flat country. [30] also says that the method is most applicable in densely gauged networks.

\subsection{Land Use/Land Cover Data Analysis Method}

Mapping LULC accurately and efficiently using remote sensing images requires a good image classification method. Unfortunately, there are many factors which could affect the effectiveness and accuracy of the classification. The maximum likelihood pixel-based on classification method, which was developed in the 1970s, is the most commonly method used on Landsat images processing [31] [32]. This method was used to produce the LULC maps for the years 1990, 2000 and 2016 by considering five (5) LULC types namely: urban area, shrubs, agricultural, forest and water (Table 2).

The maximum likelihood method calculates according to the reflectance of the pixels, the probability of their belonging to a given class. The pixel is assigned to 
Table 2. Land use/land cover classification scheme.

\begin{tabular}{cl}
\hline LULC categories & \multicolumn{1}{c}{ Description } \\
\hline Urban area or built-up & $\begin{array}{l}\text { urbanized areas and roads as well as land covered by buildings and other } \\
\text { mareas, mixed urban and built up lands }\end{array}$ \\
& $\begin{array}{l}\text { some woody plants, smaller than a tree, usually having multiple } \\
\text { permanent stems branching from or near, the ground or woody plants of } \\
\text { relatively low height, having several stems arising from the base and } \\
\text { lacking a single trunk }\end{array}$ \\
Shrubs & $\begin{array}{l}\text { the farmland areas or the lands covered with temporary crops followed } \\
\text { by harvest period, crop fields and pastures }\end{array}$ \\
Agriculture & growth of trees and other plants covering a large area \\
Forest & the stream line, lagoon
\end{tabular}

the class with the highest probability. Geometric errors, misclassifications, and undefined classes can affect Land classification and produce errors. To statistically quantify these errors, a random selection of pixels of the classified maps was performed to build a confusion matrix [33]. In order to validate the land cover classification, an accuracy assessment in the form of an error matrix was performed as recommended by [34], and the kappa coefficient was used as the statistical parameter. The kappa coefficient $(K)$ determination is given by Equation (1), is multivariate used in accuracy assessment of thematic maps. It is an efficient method to derive information from an image via the confusion matrix. $K>0.80$ represents strong agreement and good accuracy; $K$ between 0.40 and 0.80 indicates a moderate accuracy, and $K<0.40$ represents a poor accuracy [35] The overall accuracy and producer's accuracy based on the produced confusion matrix were determined using Equation (2).

Spectral signature analysis of satellite images has identified five main classes of land use:

The kappa coefficient is given by the Equation (1).

$$
K=\frac{N \sum_{i=1}^{r} x_{i j}-\sum_{i=1}^{r}\left(x_{i+} \times x_{+i}\right)}{N^{2}-\sum_{i=1}^{r}\left(x_{i+} \times x_{+i}\right)}
$$

where $r$ is the number of rows in the matrix, $x_{i j}$ is the number of observations in row $i$ and column $i, x_{i+}$ and $x_{+i}$ are the marginal totals of row $i$ and column $i$, respectively, and $N$ is the total number of observations.

$$
\text { Overall accuracy }=\frac{\text { Number of orrected pixel }}{\text { Total number of elected pixel }} \times 100
$$

\subsection{Groundwater Recharge Estimation Using Water Balance Method}

Groundwater recharge is not easy to estimate mainly in the urban area. In fact, it depends on several factors such as climatic forcing, nature of soil and land use [36]. Furthermore, there are many methods to estimate Groundwater recharge. 
In this study, Groundwater recharge was estimated using the water balance method by considering monthly infiltration. This recharge is computed by monthly mean area precipitation (1983-2017) based on the Thornthwaite flowchart. This method has been used in 1996 by SOGREAH on the Abidjan aquifer. It allows calculating the monthly infiltration rate from Equation (3) [37] [38]

$$
P=\mathrm{AET}+R+I+\Delta S
$$

with $P$ : total rainfall $(\mathrm{mm})$

AET: actual evapotranspiration $(\mathrm{mm})$,

$R:$ runoff $(\mathrm{mm})$,

I: infiltration,

$\Delta S$ : water stock variation in the available water content (AWC).

\subsubsection{Actual Evapotranspiration (AET)}

The AET is the amount of water which is actually evaporated and depends on many parameters such as: precipitation, temperature, insolation, wind, vegetation, nature of the soil, useful soil reserve [39]. To estimate this parameter, there are many methods; however in this study Thornthwaite method was used. It is a widely used empirical method for estimating evapotranspiration and the only variable used is monthly temperature.

\subsubsection{Surface Runoff Determination}

The surface runoff $(\mathrm{R})$ was predicted using a hydrological model which utilizes the USDA (United States Department of Agriculture) procedure for the estimation of surface runoff which is based on the SCS-CN (Soil Conservation Service Curve Number) method. The flowchart in Figure 4 summarizes the methodology adopted for the runoff estimation. After using the satellite image to determine the LULC cover of the area, the identified soil types at the study were distributed into hydrological soil groups (A, B, C and D) according to the infiltration capacity of soil (Table 3 ). The area of each polygon with a unique assigned curve number was determined from the superimposed LULC and hydrological soil group based on standard SCS curve number (Table 4). The SCS-CN approach is a frequently used empirical method based on the water balance approach to estimate the direct runoff from a watershed [40]. The curve number for each drainage basin of area-weighting was calculated from the land use-soil group polygons within the drainage basin boundaries [41]. Daily rainfall data was chosen because the Antecedent moisture condition classes (Table 3) of the soil can only be computed using total precipitation for five successive days preceding a storm. To estimate the Runoff Depth, curve numbers (CNs) were first assigned based on computed Antecedent Moisture Condition (AMC) that represents five-day precipitation.

Potential maximum retention $(S)$ was then computed using the equation (4) below

$$
S=\frac{1000}{C N}-10
$$


Table 3. Hydrological soil group and their characteristics [43].

\begin{tabular}{cccc}
\hline Group & \multicolumn{2}{c}{ Infiltration rate $(\mathrm{mm} / \mathrm{hr})$} & Soil texture \\
\hline A & High & $>25$ & Sand, loamy sand or sandy loam \\
B & Moderate & $12.5-25$ & Silt loam or loam \\
C & Low & $2.5-12.5$ & Sandy clay loam \\
D & Very low & $<2.5$ & Clay loam, silty clay loam, sandy clay, silty clay or clay \\
\hline
\end{tabular}

Table 4. Antecedent moisture condition classes.

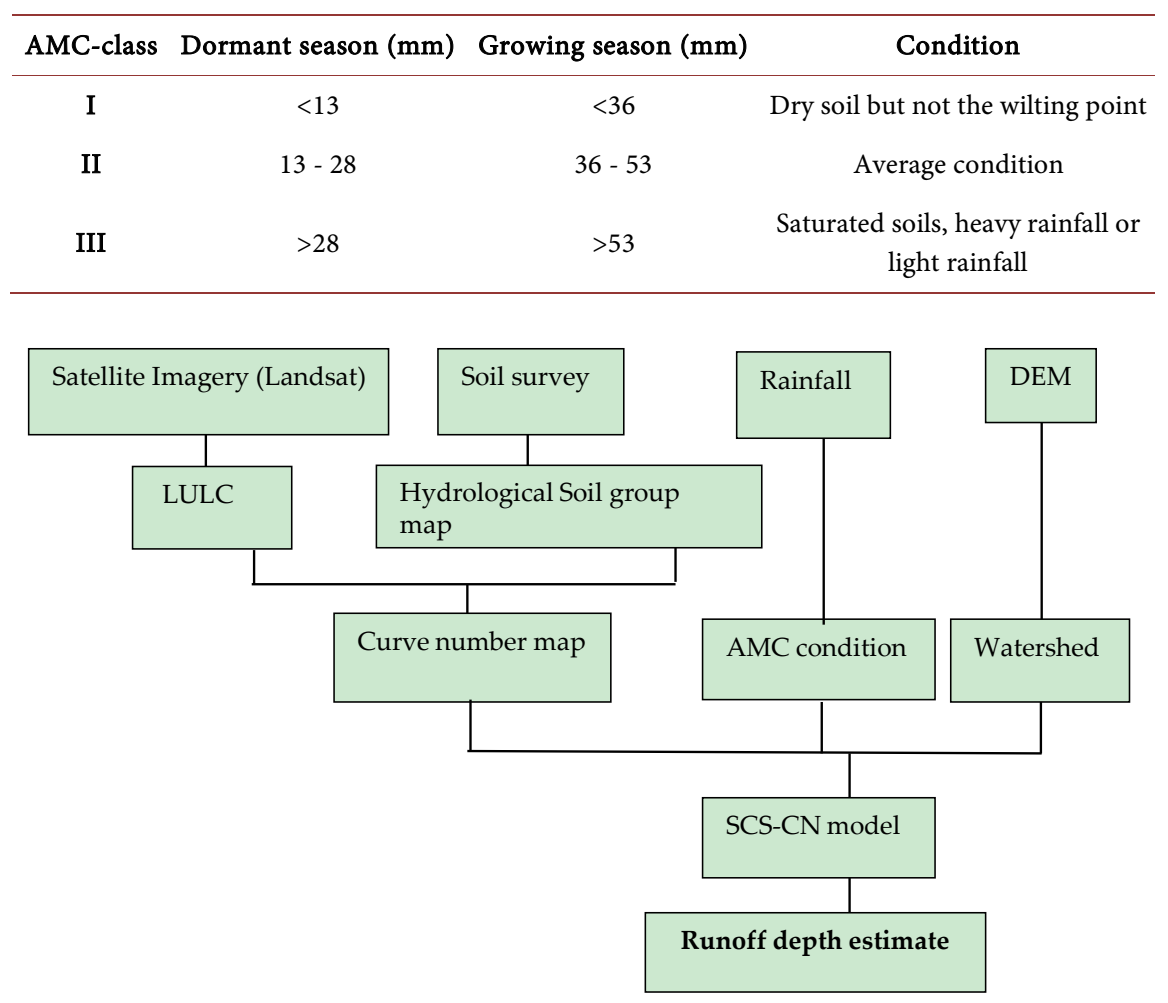

Figure 4. The methodology flow diagram [40].

Subsequently, initial abstraction (surface storage, interception, and infiltration) was computed using the following equation:

$$
I_{a}=0.2 S
$$

For all values with precipitation greater than the initial abstraction $\left(I_{a}\right)$, the daily runoff depth for all the specific days of the year was computed using the SCS-CN Equation (6) [42]

$$
R=\left\{\begin{array}{cl}
0, & \text { for } P \leq I_{a} \\
\frac{\left(P-I_{a}\right)^{2}}{\left(P-I_{A}+S\right)}, & \text { for } P>I_{a}
\end{array}\right.
$$

where:

$$
\begin{aligned}
& R=\operatorname{runoff}(\mathrm{mm}) \\
& P=\operatorname{rainfall}(\mathrm{mm})
\end{aligned}
$$


$I_{a}=$ Initial abstraction (surface storage, interception, and infiltration, $\mathrm{mm}$ )

$S=$ potential maximum retention $(\mathrm{mm})$

$C N$ has a range from 30 to 100 ; lower numbers indicate low runoff potential, while larger numbers are for higher runoff potential. The lower the curve number the more permeable the soil.

\subsubsection{Antecedent Moisture Condition Classes}

Soil water content on the day of the storm is accounted for by an antecedent moisture condition (AMC) determined by the total rainfall in the 5-day period preceding the storm. Three AMC groups have been established with the boundaries between groups dependent upon the time of year as shown in Table 4. As time of year there is growing season which is the part of the year during which rainfall and temperature allow plants to grow and dormant season is the time when a plant has naturally stopped growing.

\section{Results}

\subsection{Classification Accuracy}

The results for the Landsat images classification accuracy for the three LULC maps evaluated using confusion matrix are shown in Table 5. An overall accuracy and a kappa index of $98.29 \%$ and 0.97 for the year 1990, $99.90 \%$ and 0.99 for 2000 and $93.80 \%$ and 0.92 for 2016 were obtained. The confusion matrix highlights the map accuracies ranging from $94 \%$ to $100 \%$ in 1990. In 2000 these accuracies are from $99 \%$ to $100 \%$ and from $78 \%$ to $98 \%$ in 2016 . The results reveal satisfactory values of kappa coefficient $(>0.90)$ and cartographic accuracy of more than $90 \%$. According to [43], a Kappa index of more than 0.50 indicates that the classified LULC map can be used for further analysis. These results are close to those of several studies such as [16] [31] [32] [44] [45].

\subsection{Spatio-Temporal Changes in Land Use and Land Cover}

Figure 5 shows the maps of LULC changes over the Continental Terminal for 1990, 2000 and 2016 periods.

Table 5. Confusion matrix of study area land cover classification of 1990, 2000 and 2016.

(a)

\begin{tabular}{|c|c|c|c|c|c|c|c|c|}
\hline \multirow{2}{*}{ LULC 1990} & \multicolumn{5}{|c|}{ Reference image } & \multirow{2}{*}{$\begin{array}{l}\text { Number of } \\
\text { classified pixel }\end{array}$} & \multirow{2}{*}{$\begin{array}{c}\text { User } \\
\text { accuracy (\%) }\end{array}$} & \multirow{2}{*}{$\begin{array}{c}\text { Commission } \\
\text { error }(\%)\end{array}$} \\
\hline & 1 & 2 & 3 & 4 & 5 & & & \\
\hline 1-Urban area & 100 & 0.33 & 0.00 & 0.00 & 0.80 & 721 & 98.77 & 1.23 \\
\hline 2-Shrubs & 00.00 & 96.08 & 4.92 & 0.48 & 0.23 & 613 & 96.56 & 3.44 \\
\hline 3-Agriculture & 0.00 & 3.59 & 94.10 & 0.00 & 0.00 & 305 & 92.88 & 7.12 \\
\hline 4-Forest & 0.00 & 0.00 & 0.98 & 99.52 & 0.23 & 838 & 99.40 & 0.60 \\
\hline 4-Water & 0.00 & 0.00 & 0.00 & 00.00 & 98.74 & 872 & 100 & 00 \\
\hline Producer's accuracy (\%) & 100 & 96.08 & 94.10 & 99.52 & 98.74 & & & \\
\hline Omission error (\%) & 0.0 & 0.00 & 0.00 & 0.03 & 0.37 & & & \\
\hline
\end{tabular}


(b)

\begin{tabular}{|c|c|c|c|c|c|c|c|c|}
\hline \multirow{2}{*}{ LULC 2000} & \multicolumn{5}{|c|}{ Reference image } & \multirow{2}{*}{$\begin{array}{c}\text { Number of } \\
\text { classified pixel }\end{array}$} & \multirow{2}{*}{$\begin{array}{c}\text { User } \\
\text { accuracy (\%) }\end{array}$} & \multirow{2}{*}{$\begin{array}{c}\text { Commission } \\
\text { error (\%) }\end{array}$} \\
\hline & 1 & 2 & 3 & 4 & 5 & & & \\
\hline 2-Shrubs & 00.00 & 100 & 0.00 & 0.00 & 0.00 & 662 & 100 & 0.00 \\
\hline 3-Agriculture & 0.00 & 1.96 & 100 & 0.00 & 0.00 & 409 & 100 & 0.00 \\
\hline 4-Forest & 0.00 & 0.00 & 0.00 & 99.97 & 0.23 & 1059 & 100 & 0.00 \\
\hline 4-Water & 0.00 & 0.00 & 0.00 & 00.00 & 99.63 & 858 & 100 & 00 \\
\hline Producer's accuracy (\%) & 100 & 100 & 100 & 99.97 & 98.74 & & & \\
\hline Omission error (\%) & 0.0 & 3.92 & 5.90 & 0.48 & 1.26 & & & \\
\hline
\end{tabular}

(c)

\begin{tabular}{|c|c|c|c|c|c|c|c|c|}
\hline \multirow{2}{*}{ LULC 2016} & \multicolumn{5}{|c|}{ Reference image } & \multirow{2}{*}{$\begin{array}{c}\text { Number of } \\
\text { classified pixel }\end{array}$} & \multirow{2}{*}{$\begin{array}{c}\text { User } \\
\text { accuracy (\%) }\end{array}$} & \multirow{2}{*}{$\begin{array}{c}\text { Commission } \\
\text { error (\%) }\end{array}$} \\
\hline & 1 & 2 & 3 & 4 & 5 & & & \\
\hline 2-Shrubs & 1.37 & 78.01 & 3.32 & 0.28 & 0.00 & 1064 & 95.62 & 4.38 \\
\hline 3-Agriculture & 0.00 & 18.61 & 96.68 & 1.35 & 0.00 & 241 & 51.78 & 48.22 \\
\hline 4-Forest & 2.38 & 3.38 & 0.00 & 97.59 & 0.23 & 1412 & 94.45 & 5.55 \\
\hline 5-Water & 0.00 & 0.00 & 0.00 & 00.00 & 98.53 & 1294 & 100 & 00 \\
\hline Producer's accuracy (\%) & 96.25 & 78.01 & 96.68 & 97.59 & 98.53 & & & \\
\hline Omission error (\%) & 3.74 & 21.99 & 3.32 & 2.41 & 1.47 & & & \\
\hline
\end{tabular}

The LULC statistic results in Figure 5 shows that water bodies occupy most parts of the southern and the eastern part of the catchment with almost the same proportion from 1990 to 2016. The forest was found to be decreasing in size over time from 1990 to 2016. In fact, forest land was being cleared and converted into a shrubland, cropland or urban area. However, the urban area which affects the permeability of the soil is present in the central part of the study area and in the south eastern part in 1990, and spreads across the entire study area in the year 2000. The urban area was observed to be increasing at a higher rate from the year 1990 to 2016. Furthermore, shrubland which also affects soil permeability was scattered throughout the basin in 1990, same to the forest area and decreased in 2000 and 2016 due to the rapid increase of build-up. The agriculture land was found to occupy the smallest area within the watershed and to increase steadily over time (Figure 6).

\subsection{Development of Hydrological Soil Group Map}

The soil map was used to develop the hydrological soil group map which is a group of soils having similar runoff potential under similar storm and cover conditions (Figure 7) by assigning appropriate values for the different types of soil. The soil types of the study area consisted of clay sand of lowlands, clay sands and ferruginous sandstone of the highlands, sea cords sand, vases and 

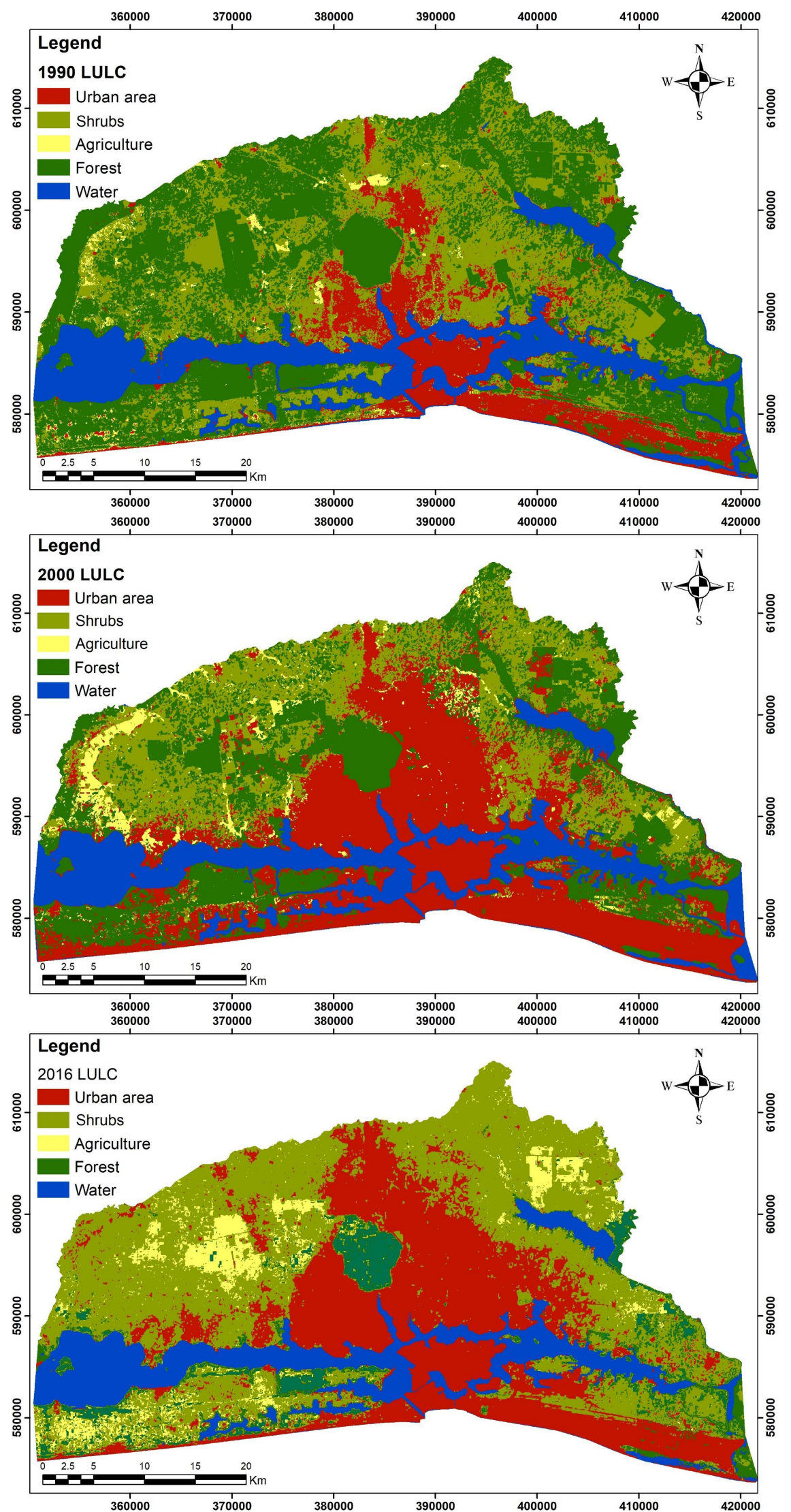

Figure 5. Study area land use land cover map in 1990, 2000 and 2016. 


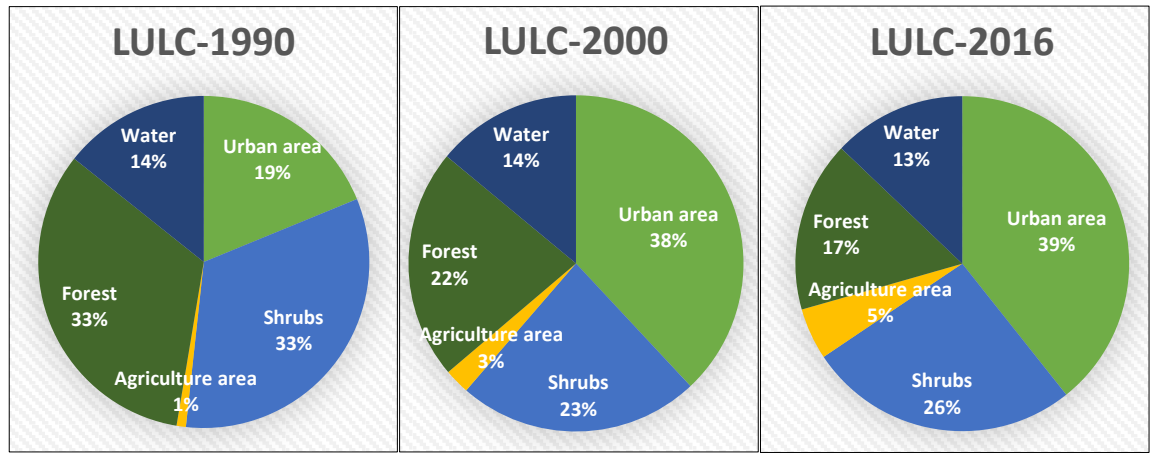

Figure 6. Proportion of land use land cover type in 1990, 2000 and 2016.

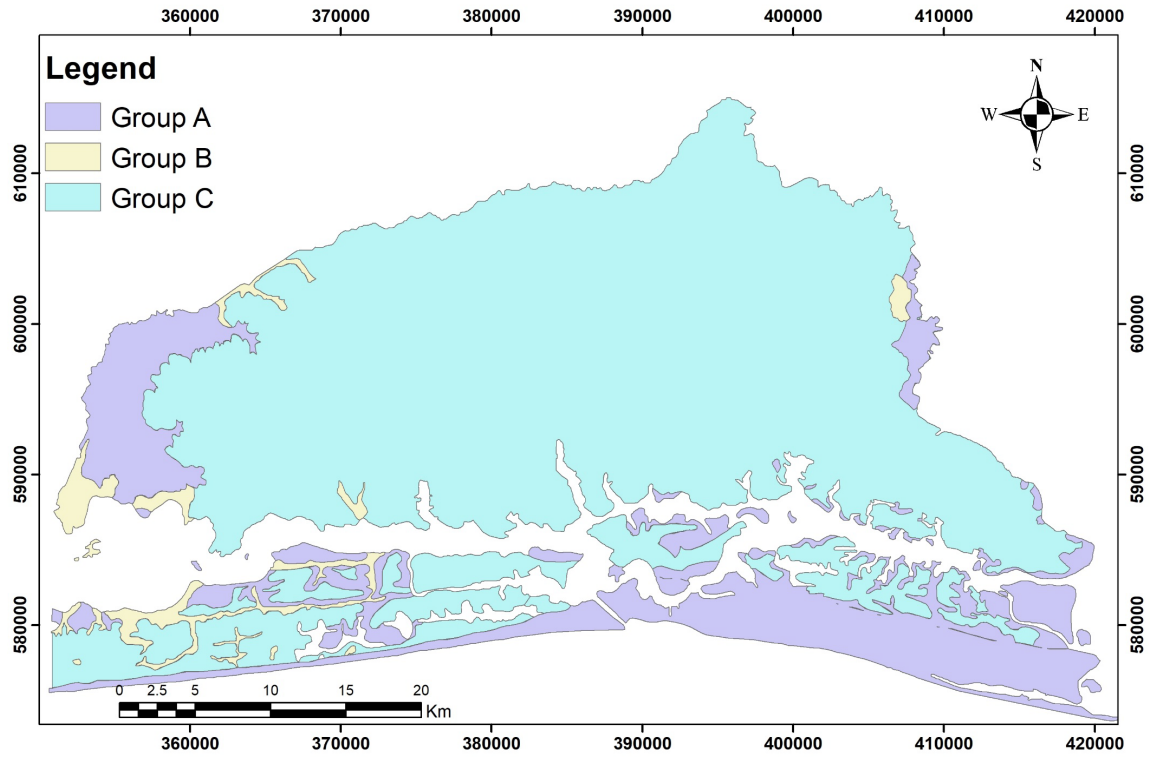

Figure 7. Hydrological soil group (HSG) map of the study area.

leached sands land vases of permanent marshlands. Based on the infiltration characteristics of the soil, the present study area soil was classified under different hydrological soil group as well as five. The major soil type in the study area is clay sands and ferruginous sandstone of the highlands (Figure 2) which occupies around $77.82 \%$ of the study area.

\subsection{Curve Number Change and Impacts on Runoff and Recharge in the Study Area}

Twelve curve numbers were derived from the three HSG and five LULC classes as shown in the Curve Number maps in Figure 8 and Table 6 for the three LULC maps for the year 1990, 2000 and 2016. The curve number ranges from 30 to 100 ; the lower numbers indicate low runoff potential while the larger numbers indicate high runoff potential. The lower curve numbers the more permeable the soil. These maps reveal that in 1990, the study area was dominated by low weighted curve number which led to a low runoff and higher recharge, while 2000 is marked by an increase of weighted curve number zone which favors an 

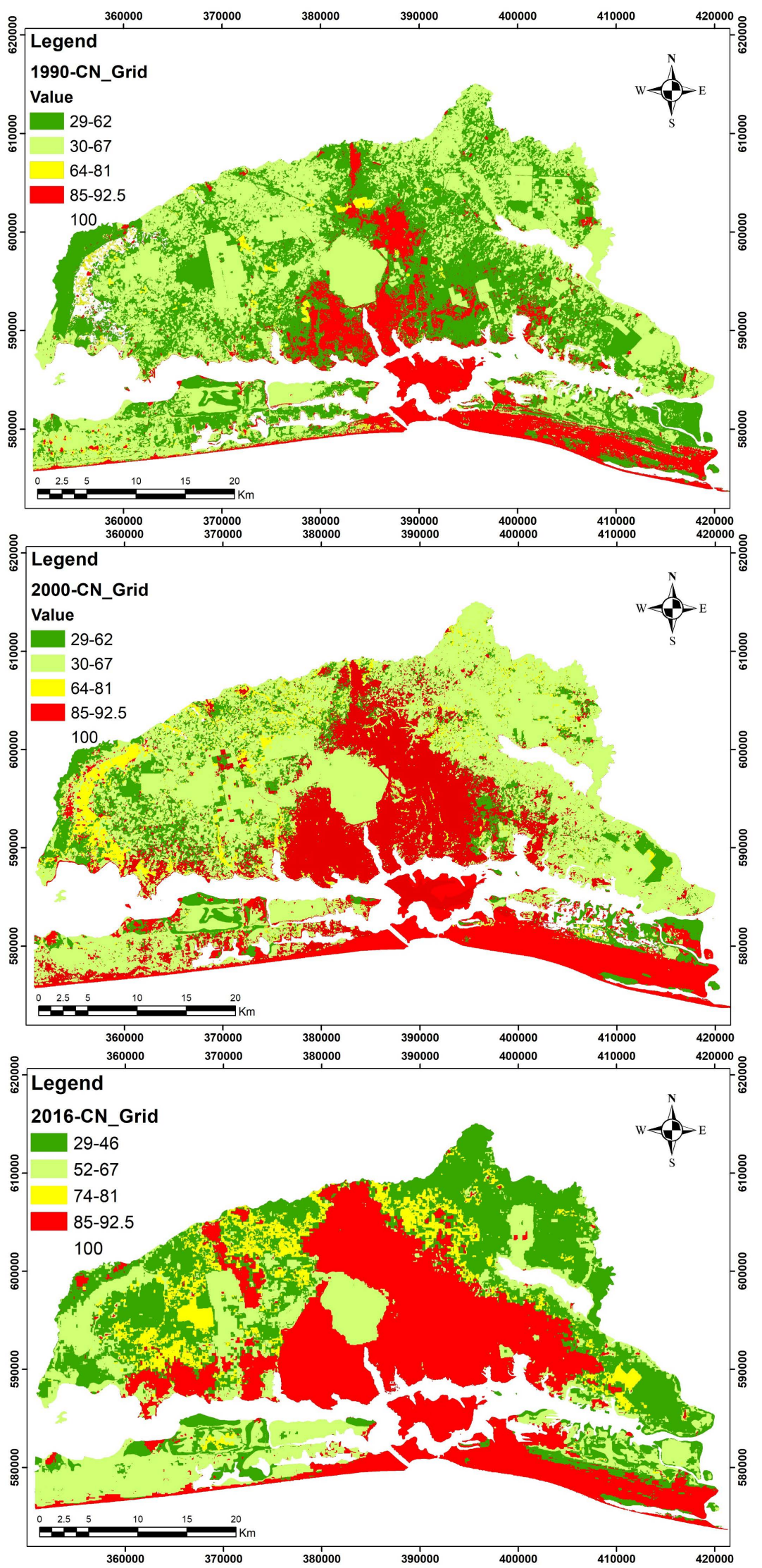

Figure 8. Weighted curve number map based on different soil groups and LULC types. 
Table 6. Weighted curve number of the group of soil and surface of land cover type.

\begin{tabular}{|c|c|c|c|c|c|c|c|c|c|c|c|}
\hline \multirow[b]{2}{*}{ Land cover } & \multirow[b]{2}{*}{ Soil } & \multirow[b]{2}{*}{$\mathrm{CN}$} & \multicolumn{3}{|c|}{1990} & \multicolumn{3}{|c|}{2000} & \multicolumn{3}{|c|}{2016} \\
\hline & & & $\begin{array}{c}\text { Surface } \\
\left(\mathrm{km}^{2}\right)\end{array}$ & $\begin{array}{c}\text { Percent } \\
\text { Area }\end{array}$ & $\begin{array}{c}\mathrm{CN}^{*} \text { Percent } \\
\text { Area }\end{array}$ & $\begin{array}{l}\text { Surface } \\
\left(\mathrm{km}^{2}\right)\end{array}$ & $\begin{array}{c}\text { Percent } \\
\text { Area }\end{array}$ & $\begin{array}{c}\mathrm{CN}^{*} \text { Percent } \\
\text { Area }\end{array}$ & $\begin{array}{c}\text { Surface } \\
\left(\mathrm{km}^{2}\right)\end{array}$ & $\begin{array}{c}\text { Percent } \\
\text { Area }\end{array}$ & $\begin{array}{c}\mathrm{CN}^{*} \text { Percent } \\
\text { Area }\end{array}$ \\
\hline \multirow{3}{*}{ Urban area } & A & 85 & 130.96 & 8.27 & 702.55 & 170.10 & 10.74 & 912.52 & 124.81 & 7.88 & 669.56 \\
\hline & $\mathrm{B}$ & 90 & 29.10 & 1.84 & 53.26 & 29.60 & 1.87 & 54.18 & 74.54 & 4.70 & 136.43 \\
\hline & $\mathrm{C}$ & 92.5 & 3.48 & 0.22 & 14.06 & 20.47 & 1.29 & 82.68 & 2.08 & 0.13 & 8.40 \\
\hline \multirow{3}{*}{ Shrubs } & A & 29 & 126.64 & 7.99 & 231.79 & 75.4 & 4.76 & 138.00 & 90.57 & 5.72 & 165.77 \\
\hline & B & 46 & 16.82 & 1.06 & 106.16 & 11.44 & 0.72 & 72.20 & 15.01 & 0.95 & 94.73 \\
\hline & $\mathrm{C}$ & 62 & 3.64 & 0.23 & 20.68 & 10.17 & 0.64 & 57.77 & 1.17 & 0.07 & 6.65 \\
\hline \multirow{2}{*}{$\begin{array}{l}\text { Agriculture } \\
\text { area }\end{array}$} & A & 64 & 8.65 & 0.55 & 25.11 & 5.08 & 0.32 & 14.75 & 11.95 & 0.75 & 34.69 \\
\hline & $\mathrm{C}$ & 81 & 29.27 & 1.85 & 96.06 & 24.32 & 1.53 & 79.82 & 29.34 & 1.85 & 96.29 \\
\hline \multirow{3}{*}{ Forest } & A & 29 & 2.14 & 0.14 & 13.51 & 1.36 & 0.09 & 8.58 & 1.55 & 0.10 & 9.78 \\
\hline & $\mathrm{B}$ & 52 & 201.67 & 12.73 & 1177.35 & 445.06 & 28.09 & 2598.25 & 462.53 & 29.19 & 2700.24 \\
\hline & $\mathrm{C}$ & 67 & 523.53 & 33.04 & 2048.59 & 170.95 & 10.79 & 668.93 & 396.26 & 25.01 & 1550.58 \\
\hline \multirow{3}{*}{ Water } & A & 100 & 12.50 & 0.79 & 63.90 & 60.57 & 3.82 & 309.64 & 85.81 & 5.42 & 438.68 \\
\hline & B & 100 & 447.81 & 28.26 & 1893.61 & 518.45 & 32.72 & 2192.32 & 245.39 & 15.49 & 1037.66 \\
\hline & $\mathrm{C}$ & 100 & 47.50 & 3.00 & 299.79 & 37.97 & 2.40 & 239.64 & 43.01 & 2.71 & 271.45 \\
\hline TOTAL & & & 1584.45 & 100.00 & 6749.86 & 1584.45 & 100.00 & 7445.69 & 1584.41 & 100.00 & 7222.73 \\
\hline
\end{tabular}

increase in the runoff and the decline of recharge in the study area. However, recharge areas identifying areas with low runoff capacity, therefore having a low weighted curve number reappear in 2016.

\subsection{Seasonal and Inter-Annual Variability of Rainfall, Recharge and Runoff}

The results (Table 7) reveal a decrease in rainfall over time while the recharge shows a decrease from 1990 to 2000 and an increase in 2016. However, runoff increased considerably from 1990 to 2000 and decreased in 2016 (Figure 9(A)). Inter-annual variability shows that in 2000 when rainfall and recharge were decreasing, runoff was increasing. This period is marked by a strong increase in urbanization in the study area. Figure $9(\mathrm{~A})$ and Figure $9(\mathrm{~B})$ show the inter-annual variability and seasonal trends of rainfall, runoff and recharge for the year 1990, 2000 and 2016. The seasonal recharge from April to July was high and the peak was observed in June $(174 \mathrm{~mm})$ during the year 1990. The recharge decreased in September, November and December. In 2000, the higher values of recharge were observed in May and June and get down in April, July and October. The peak was also in June with $139 \mathrm{~mm}$. The year 2016 is characterized by a high value of recharge in May and June where the peak was observed in June (175 mm). The low value of recharge is observed in March, April and October. 
Runoff is proportional to recharge and presents lower values compared to recharge. Seasonal variability shows that the recharge is changing from one month to the next and that is due to rainfall variability.

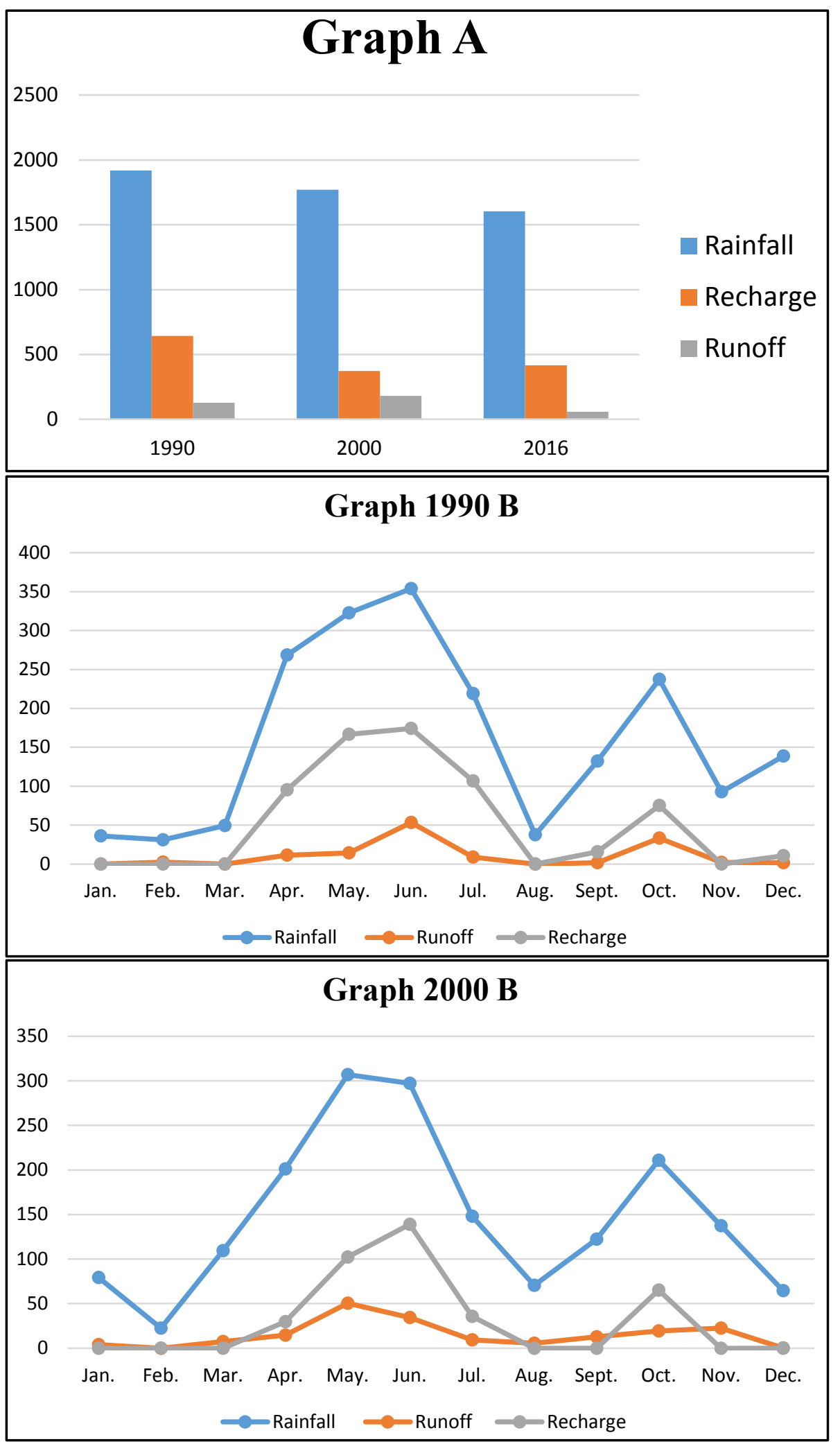




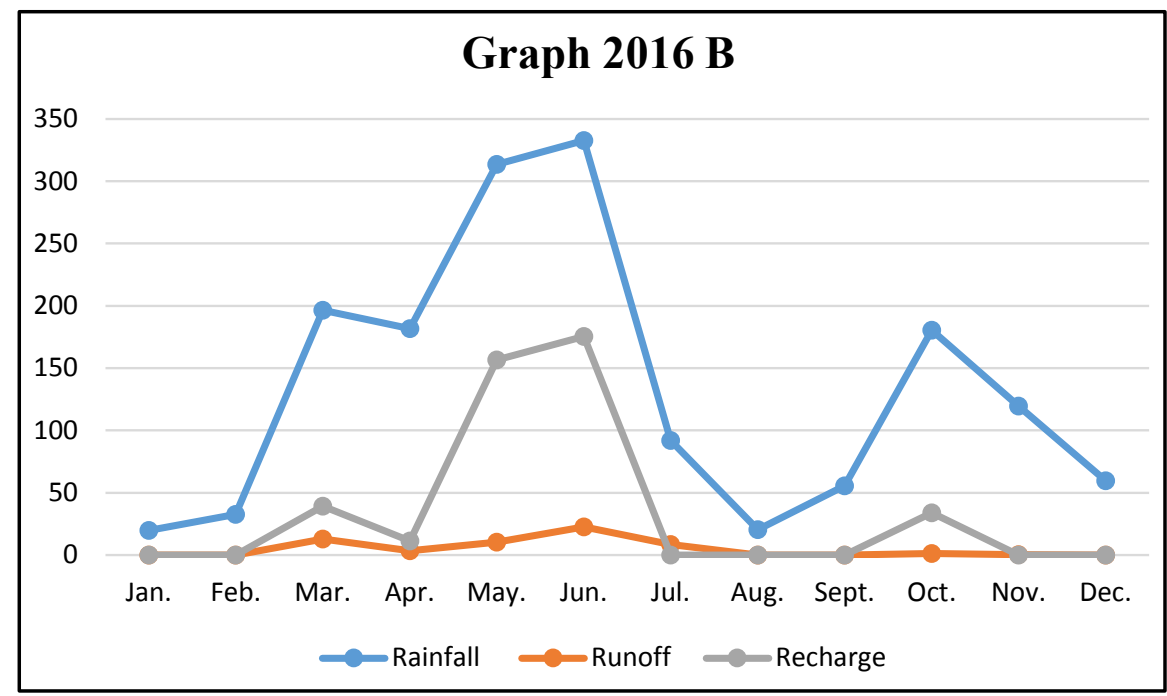

Figure 9. Seasonal and inter annual variability of rainfall, recharge and runoff.

Table 7. Monthly rainfall, runoff and recharge.

\begin{tabular}{cccccccccc}
\hline \multicolumn{3}{c}{1990} & \multicolumn{3}{c}{2000} & \multicolumn{3}{c}{2016} \\
\hline Date & $\begin{array}{c}\text { Rainfall } \\
(\mathrm{mm})\end{array}$ & $\begin{array}{c}\text { Runoff } \\
(\mathrm{mm})\end{array}$ & $\begin{array}{c}\text { Recharge } \\
(\mathrm{mm})\end{array}$ & $\begin{array}{c}\text { Rainfall } \\
(\mathrm{mm})\end{array}$ & $\begin{array}{c}\text { Runoff } \\
(\mathrm{mm})\end{array}$ & $\begin{array}{c}\text { Recharge } \\
(\mathrm{mm})\end{array}$ & $\begin{array}{c}\text { Rainfall } \\
(\mathrm{mm})\end{array}$ & $\begin{array}{c}\text { Runoff } \\
(\mathrm{mm})\end{array}$ & $\begin{array}{c}\text { Recharge } \\
(\mathrm{mm})\end{array}$ \\
\hline Jan & 36 & 0 & 0 & 79 & 4 & 0 & 20 & 0 & 0 \\
Feb & 31 & 2 & 0 & 23 & 0 & 0 & 33 & 0 & 0 \\
March & 49 & 0 & 0 & 110 & 7 & 0 & 197 & 13 & 39 \\
April & 269 & 11 & 95 & 201 & 15 & 30 & 182 & 3 & 11 \\
May & 323 & 14 & 167 & 307 & 51 & 102 & 314 & 10 & 157 \\
June & 354 & 53 & 174 & 297 & 34 & 139 & 333 & 23 & 175 \\
July & 219 & 9 & 107 & 148 & 9 & 36 & 92 & 8 & 0 \\
Aug & 37 & 0 & 0 & 70 & 6 & 0 & 20 & 0 & 0 \\
Sept & 132 & 2 & 16 & 122 & 13 & 0 & 56 & 0 & 0 \\
Oct & 237 & 33 & 75 & 211 & 20 & 65 & 180 & 1 & 34 \\
Nov & 93 & 2 & 0 & 137 & 22 & 0 & 120 & 0 & 0 \\
Dec & 138 & 2 & 11 & 65 & 0 & 0 & 60 & 0 & 0 \\
Total & 1919 & 128 & 644 & 1771 & 181 & 372 & 1604 & 59 & 417 \\
\hline
\end{tabular}

\section{Discussion}

In this study, a spatial-temporal dynamics of LULC was assessed based on image classification and change detection method. The study highlights that the built-up and agricultural lands have increased rapidly in the study area. Such an increase in built-up area and agricultural lands can be explained by the increase in urbanized and cultivated areas, respectively. In addition, the decline of forestland can be explained by the expansion of agricultural and urbanized areas. In fact, forest areas are being reduced to enlarge the land use areas or, forest areas 
are converted in agricultural and built up area. This increase in urbanization after 2000 could be explained by rural exodus of urban center population, as well as population growth, and is supported by [46] who indicated that urban sprawl in Abidjan from 2002 to 2014 is mainly due to population growth during the crisis (2002-2011) and its demand for development. Indeed, due to the country's crisis which started in 2001, population migration significantly increased (rapid uncontrolled urbanization) from the north to the southern part of the country, mainly to Abidjan. The urbanization is linked to the economic progress. The same conclusion was made by [47], who explained that the economic capital of Ivory Coast with developmental projects including construction of roads, houses and industries, as well as population growth are still increasing and therefore areas covered by vegetation are expected to be further transformed to urban areas.

Furthermore, three hydrological soil groups namely A, B and C were found to dominate the watershed with hydrological soil group $\mathrm{C}$ having the high runoff potential. This is because the hydrological soil group $\mathrm{C}$ lies in the urban area; hence limiting infiltration and favoring runoff. The southeastern parts of the watershed were found to be dominated by hydrological soil group A, which has low runoff potential. This is mainly due to the presence of agricultural lands in this section. The crops require more water hence increasing the rate of infiltration which in turn leads to lower runoff potential, and hydrological soil group B characterize by moderate runoff. It is important to mention that hydrological soil group must be associated with LULC to know the infiltration capacity of the soil. For instance, the hydrological soil group A located at the southeastern part of the study area is converted into urban area which is therefore favorable to high runoff. The LULC changes have an important effect on the catchment runoff generation [48].

In addition, comparing maps of curve number during the years 1990, 2000 and 2016, the amount of weighted curve number value estimated for the study area was increased because of the increase in the urban area, showing human interventions in the landscape during that period. During the years 2000 to 2016, the level of forestland decreased by $4 \%$ and some part were converted in croplands. This made possible the increasing of recharge in this period. A similar conclusion was reported by [49], who found that dry agricultural land could increase groundwater recharge in the southwestern US.

The results show a temporal variability of the recharge on Abidjan aquifer. The methodology uses to find the recharge highlight runoff variability which brings out the impact of urbanization, shrubs area and agricultural land on groundwater recharge. Thus, the changes in recharge are due to rainfall variability and LULC change over time. Moreover, it is observed that the recharge decreases considerably, almost to a half from 1990 to 2000. This period is marked by a strong increase of urbanization in the study area which favors the increase of runoff from 128 to $181 \mathrm{~mm}$. However, the study reveals an increase in re- 
charge in 2016 which is due to the increase of afforested area and agricultural land. In fact, it was observed that covered area favored high infiltration and represents a low weight of curve number which expresses low runoff. However, low infiltration occurs in urban areas where weighted curve number is high and expresses high runoff. The results are in accordance with the study of [10] and some previous studies in West Africa [50] and [51] provide a numbered reference for Baier et al., who affirm that the rapid growth of urban area has two basic effects on groundwater resources such as effects on natural recharge of aquifers due to sealing of ground with concrete and pollution of groundwater due to leakage from drainage and industrial waste and effluents. Furthermore the annual recharge was estimated at $400 \mathrm{~mm} /$ year in 2016, this value represents about the double of the results of the study undertaken by [46] this could be explained by the difference in methods used but this result is close to the previous study of [16] who assess the recharge at $342 \mathrm{~mm} /$ year in 2006.

\section{Conclusion and Recommendation}

This study attempts to bring out influence of LULC change on groundwater recharge for Continental Terminal from 1990 to 2016 using climate stations data and satellite image data utilizing several methods. The study revealed that LULC dynamic is dominated by urbanization area which was increasing from $16 \%$ (1990) to 39\% (2016). Such a phenomenon had an impact on groundwater recharge in this period. The weight curve number value estimated for the study area is increasing during the study period and that caused an increase in runoff estimates. However, in 2016 it was observing the increase of groundwater recharge which is due to vegetation restoration linked to cultural areas extension. Furthermore, the study also revealed that rainfall is the most important parameter which influences the recharge during wet season and interannually, it is influenced by both driver, rainfall and LULC change. The outcome of this study gives an insight into the issue of water supply in Abidjan city. In fact this city depends on water supply of the groundwater; therefore to have an idea of the recharge variability could help to predict future water management in the context of climate change and population growth which is not followed by adequate infrastructure. This serves as a guide in developing policies to mitigate the lack of water observed in recent decades.

\section{Author Contributions}

K.K.A., Y.N., L.S, I.O., O.M., K.K.A, B.K., and K.D. designed the study, developed the methodology and wrote the manuscript. K.KA. collected the data and performed the analysis; O.I, O.M, L.S, supervised the data analysis; L.S an O.I contributed to paper write up.

\section{Funding}

This research received no external funding. 


\section{Acknowledgements}

This paper was extracted from a Doctoral research study undertaken at Universite of Abomey-Calavi, Benin. My sincere appreciation goes to the Federal Ministry of Education and Research (BMBF) and West African Science Centre on Climate Change and Adapted Land Use (WASCAL; www.wascal.org) for providing the scholarship and financial support for this programme.

\section{Conflicts of Interest}

The authors declare no conflict of interest.

\section{References}

[1] Ramsey, M.S. (2003) Mapping the City Landscape from Space: The Advanced Spaceborne Thermal Emission and Reflectance Radiometer (ASTER) Urban Environmental Monitoring Program. In: Heiken, G., Fakundiny, R. and Sutter, J., Eds., Earth Sciences in the City, American Geophysical Union, Washington, DC, Vol. 9, 337-376. https://doi.org/10.1029/SP056p0337

[2] John, M. and Sharp, J. (2010) The Impact of Urbanization on Groundwater System and Recharge.

[3] Arnold, C.L.J. and Gibbons, C.J. (1996) Impervious Surface Coverage: The Emergence of a Key Environmental Indicator. Journal of the American Planning Association, 62, 243-258. https://doi.org/10.1080/01944369608975688

[4] Baier, K., Schmitz, K.S., Azzam, R. and Strohschon, R. (2014) Management Tools for Sustainable Ground Water Protection in Mega Urban Areas-Small Scale Land Use and Ground Water Vulnerability Analyses in Guangzhou, China. International Journal of Environmental Research, 8, 249-262.

[5] Moeck, C., Radny, D., Popp, A., et al. (2017) Characterization of a Managed Aquifer Recharge System Using Multiple Tracers. Science of the Total Environment, 609, 701-714.https://doi.org/10.1016/j.scitotenv.2017.07.211

[6] Michel, C. and Philipe, D. (1982) L'assainissement de la ville d'Abidjan rapport d'expertise.

[7] Dongo, K., Kouamé, K.F. and Koné, B. (2008) Analyse de la situation de l'environnement sanitaire des quartiers défavorisés dans letissu urbain de Yopougon à Abidjan, Côte d'Ivoire. VertigO, 8, 1-11. https://doi.org/10.4000/vertigo.6252

[8] Jourda, J.R.P., Kouamé, K.J., Saley, M.B., Kouadio, B.H. and Oga, Y.S. (2006) Contamination of the Abidjan Aquifer by Sewage: An Assessment of Extent and Strategies for Protection. In: Yongxin, X. and Brent, U., Eds., Groundwater Pollution in Africa Balkema (Grande Bretagne), Taylor Fr., London, 291-300.

[9] Pasquier, F. (1986) Hydrodynamique de la nappe du Gäu (cantons de Soleure et Berne). Thèse de Doctorat de l'Université Neuchâtel, Suisse.

[10] Soro, N., Lasm, T., Kouadio, B.H., Soro, G. and Ahoussi, K.E. (2006) Variabilité du régime pluviométrique du Sud de la Côte d'Ivoire et son impact sur l'alimentation de la nappe d'Abidjan. Sud Sciences et Technologies, 14, 30-40.

[11] Kouassi, K.A. (2013) Modélisation hydrodynamique en milieu poreux saturé par approche inverse via une paramétrisation multi-échelle: Cas de l'aquifère du Continental Terminal d'Abidjan (Côte d'Ivoire). Thèse université nangui abrogoua.

[12] Kouame, K.I. (2007) Pollution physico-chimique des eaux dans la zone de la 
décharge d'Akouédo et analyse du risque de contamination de la nappe d'Abidjan par un modèle de imulation des écoulements et du transport des polluants. Thèse unique, Université d'abobo-adjamé.

[13] Jourda, J.R.P. (1987) Contribution à l'étude géologique et hydrogéologique de la région du Grand Abidjan. Thèse de Troisième Cycle, Université de Grenoble.

[14] Sogreah (1996) Etude de la gestion et de la protection de la nappe assurant la production en eau potable d'Abidjan. Etude sur modèle mathématique. Rapport final; synthèse des résultats, volume 2, République de Côte d'Ivoire, Ministère des infrastructure.

[15] Yao, A.B., Kouame, K.I., Kouassi, K.A., Koffi, K. and Goula, I. and Savane, B.T.A. (2015) Estimation de la recharge d'une nappe côtière en zone tropicale humide: Cas de la nappe du Continental Terminal d'Abidjan (Côte d'Ivoire). International Journal of Innovation and Applied Studies, 12, 888-898.

[16] Kouakou, D.S. (2013) Contributions de l'évaluation de la vulnérabilité spécifique aux nitrates et d'un modèle de transport des organochlorés a la protection des eaux souterraines du district d'abidjan (sud de la côte d'ivoire). Thèse de l'université félix houphouët-boigny, hydrogéologie.

[17] Kouame, K.J. (2007) Contribution à la Gestion Intégrée des Ressources en Eaux (GIRE) du District d'Abidjan (Sud de la Côte d'Ivoire), Outils d'aide à la décision pour la prévention et la protection des eaux souterraines contre la pollution. Thèse de l'université de cocody en Hydrogéologie \& SIG.

[18] Schirmer, M. (2017) Characterization of a Managed Aquifer Recharge System Using Multiple Tracers. Science of the Total Environment, 609, 701-714. https://doi.org/10.1016/j.scitotenv.2017.07.211

[19] Rallison, R.E. (1980) Origin and Evolution of the SCS Runoff Equation. Proceeding of the Symposium on Watershed Management 80 American Society of Civil Engineering Boise ID.

[20] Ponce, V.M. and Hawkins, R.H. (1996) Runoff Curve Number: Has It Reached Maturity? Journal of Hydrologic Engineering, 1, 11-19. https://doi.org/10.1061/(ASCE)1084-0699(1996)1:1(11)

[21] Li, J., Liu, C.M., Wang, Z.G. and Liang, K. (2015) Two Universal Runoff Yield Models: SCS versus LCM. Journal of Geographical Sciences, 25, 311-318. https://doi.org/10.1007/s11442-015-1170-2

[22] Hong, Y. and Adler, R.F. (2008) Estimation of Global SCS Curve Numbers Using Satellite Remote Sensing and Geospatial Data. Journal International Journal of Remote Sensing, 29, 471-477. https://doi.org/10.1080/01431160701264292

[23] Muthu, A. and Santhi, M. (2015) Estimation of Surface Runoff Potential Using SCS-CN Method Integrated with GIS. Indian Journal of Science and Technology, 8 , No. 28. https://doi.org/10.17485/ijst/2015/v8i28/83324

[24] Noah, K. and Benson, M.O. (2017) Application of GIS for Estimation of Water Runoff Volume in Water Collection Sites Case Study: Northern Collector Water Tunnel. American Journal of Geographic Information System, 6, 169-177.

[25] INS (2014) Recensement général de la population et de l'habitat (RGPH), Données socio-démographiques et économique de localités, résultats définitif par district, région, département et sous-préfecture, Secrétariat Technique Permanent du Comité Technique du RGPH , 2.

[26] Tastet, J.P. (1979) Environnements sédimentaires et structuraux quaternaires du littoral du golfe de guinée (côte d'ivoire, togo, bénin). Thèse de Doctorat d'Etat ès sciences, Université de Bordeaux. 
[27] Tapsoba, S.A. (1995) Contribution à l'étude géologique et hydrogéologique de la région de Dabou (Sud de la Côte d'Ivoire): Hydrochimie, isotopie et indice cationique de vieillissement des eaux souterraines. Thèse de doctorat de l'Université $\mathrm{Na}$ tionale de Côte d'Ivoire.

[28] Papon, A. and Lemarchand, R. (1973) Géologie et minéralisation du Sud-Ouest de la Cote d'Ivoire. Abidjan. (In French)

[29] Wiesner, C. (1970) Hydrometeorology. Chapman \& Hall, London.

[30] Edwards, K. (1972) A Note on the Calculation of Mean Area Precipitation by J. Akin. Journal of Hydrology, 51, 171-173. https://doi.org/10.1016/0022-1694(72)90127-8

[31] Tra Bi, Z.A. (2013) Etude de l'impact des activités anthropiques et de la variabilité climatique sur la végétation et les usages des sols, par utilisation de la télédétection et des statistiques agricoles, sur le bassin versant du Bouregreg (Maroc). Thèse de doctorat Université Hydrosciences Montpellier.

[32] Salomon, O., et al. (2018) Assessment of Spatio-Temporal Changes of Land Use and Land Cover over South-Western African Basins and Their Relations with Variations of Discharges. Hydrology, 5, 56. https://doi.org/10.3390/hydrology5040056

[33] Obahoundje, S., Ofosu, E., Akpoti, K. and Kabo-Bah, A. (2017) Land Use and Land Cover Changes under Climate Uncertainty: Modelling the Impacts on Hydropower Production in Western Africa. Hydrology, 4, 2. https://doi.org/10.3390/hydrology4010002

[34] Congalton, R.G. (1991) A Review of Assessing the Accuracy of Classification of Remotely Sensed Data. Remote Sensing of Environment, 37, 35-46. https://doi.org/10.1016/0034-4257(91)90048-B

[35] Akpoti, K., Antwi, E. and Kabo-Bah, A. (2016) Impacts of Rainfall Variability, Land Use and Land Cover Change on Stream Flow of the Black Volta Basin, West Africa. Hydrology, 3, 26. https://doi.org/10.3390/hydrology3030026

[36] Scanlon, B.R., Keese, K.E., Flint, A.L., Flint, L.E., Gaye, C.B., Edmunds, W.M. and Simmers, I. (2006) Global Synthesis of Groundwater Recharge in Semiarid and Arid Regions. Hydrological Processes, 20, 3335-3370. https://doi.org/10.1002/hyp.6335

[37] Thorntwaite, C.W. and Mather, J.R. (1955) The Water Balance. Laboratory of Climatology, 8, 14

[38] Thorntwaite, C.W. and Mather, J. (1957) Instructions and Tables for Computing Potential Evapotranspiration and the Water Balance. Laboratory of Climatology, 10.

[39] Pidwirny, M. (2006) Actual and Potential Evapotranspiration, Fundamentals of Physical Geography.

[40] USDA (1972) Soil Conservation Service, National Engineering Handbook. Hydrology Section 4. USDA, Washington, DC.

[41] Kudoli, A. and Oak, R. (2015) Runoff Estimation by Using GIS Based Technique and Its Comparison with Different Methods-A Case Study on Sangli Micro Watershed. International Journal of Emerging Research in Management and Technology, 4, 2278-9359.

[42] Mishra, S.K. and Singh, V.P. (2003) Soil Conservation Service Curve Number (SCS-CN) Methodology. Kluwer Academic Publishers, Dordrecht. https://doi.org/10.1007/978-94-017-0147-1_1

[43] Chow, V., Maidment, D. and Mays, L. (1988) Applied Hydrology. McGraw-Hill, Inc., Boston.

[44] Pontius, R.G.J. (2000) Quantification Error versus Location in Comparison of Ca- 
tegorical Maps. Photogrammetric Engineering and Remote Sensing, 66, 1011-1016.

[45] Sawadogo, Z.K.É., Brou, Y.C., Soro, G.E. and Goula, T.B.A. (2018) Impacts De L'urbanisation Sur Les Caractéristiques Morphologiques Et Les Apports En Eau Du Barrage Hydro-Agricole De Nanan Dans Le Département De Yamoussoukro (Côte d'Ivoire). European Scientific Journal, 14, 89-110.

https://doi.org/10.19044/esj.2018.v14n12p89

[46] Berthe, Y.A., Innocent, K.K., Auguste, K.K., Kouadio, K., Goula, B.T.A. and Savane, I. (2015) Estimation de la recharge d'une nappe côtière en zone tropicale humide: Cas de la nappe du Continental Terminal d'Abidjan (Côte d'Ivoire). [Assessment of Coastal Groundwater Recharge in a Humid Tropical Zone by the Method of Thiessen: Case of Continental Terminal Aquifer.] International Journal of Innovation and Applied Studies, 12, 888-898.

[47] Danumah, J.H., Saley, M.B., Odai, S.N., Thiel, M. and Akpa, L.Y. (2017) Remote Sensing Based Analysis of the Latest Development and Structure of Abidjan District, Cote d'Ivoire. Geoinfor Geostat: An Overview, 5, No. 1. https://doi.org/10.4172/2327-4581.1000154

[48] Kalnay, E. and Ming, C. (2003) Impact of Urbanization and Land-Use Change on Climate. Nature, 423, 528-531. https://doi.org/10.1038/nature01675

[49] Scanlon, B.R., Reedy, R.C., Stonestrom, D.A., et al. (2005) Impact of Land Use and Land Cover Change on Groundwater Recharge and Quality in the Southwestern US. Global Change Biology, 11, 1577-1593. https://doi.org/10.1111/j.1365-2486.2005.01026.x

[50] Oluseyi, O.A., Victor, M., Ayobami, O.E., Oluwaseun, F.D., Akintayo, O.O. and Taiwo, J.A. (2015) Estimation of Groundwater Recharges Using Empirical Formulae in Odeda Local Government Area, Ogun State, Nigeria. Challenges, 6, 271-281. https://doi.org/10.3390/challe6020271

[51] Obuobie, E. (2008) Estimation of Groundwater Recharge in the Context of Future Climate Change in the White Volta River Basin, West Africa. Rheinische Friedrich-Wilhelms-University of Bonn, Bonn. 